\title{
On ambiguous past participles in Dutch
}

\author{
EVIE COUSSÉ
}

\begin{abstract}
This article takes up the longstanding debate on the categorization of the past participle. This construction is known to exhibit the structural and semantic features of both adjectives and verbs. In this article, the question is addressed how the past participle should be categorized in contexts where both an adjectival and a verbal analysis are equally possible (such as in clauses with the stative verb to be). Previous research has focused on determining diagnostics to discriminate between the adjectival and verbal analysis in particular contexts of usage. In this article, however, it will be argued that even a combination of all state-of-the art criteria does not guarantee a full coverage of all past participles in actual language usage. In answer to this shortcoming, an alternative viewpoint is developed in which past participles are considered to be fundamentally ambiguous, unless a preference is indicated by additional contextual elements. This inherent ambiguity of past participles is supported by the conversational maxims of quantity that state that a contribution should only be as informative as is required to fulfill the goal of the conversation. In this perspective, contextual elements that point to a resultative or a processual interpretation are only added if conversational needs require the disambiguation of the past participle.
\end{abstract}

\section{Introduction ${ }^{1}$}

Ever since the ancient grammarians, the precise categorization of the past participle has been a source of debate. Numerous scholars have demonstrated that the past participle possesses the structural and semantic features of both adjectives and verbs. The hybrid nature of the past participle can be demonstrated with the following example sentences (1) and (2), taken from modern Dutch: ${ }^{2}$ 
(1) Waarschijnlijk was hij met een aantal vrienden over probably was he with a number friends over een hek van het gesloten zwembad geklommen. a fence of the closed swimming.pool climbed 'He had probably been climbing over a fence of the closed swimming pool together with a couple of friends.'

(2) Jacques Gobert, de burgemeester van La Louvière, heeft Jacques Gobert the mayor of La Louvière has het zwembad voor onbepaalde tijd gesloten. the swimming.pool for indeterminate time closed 'Jacques Gobert, the mayor of La Louvière, has closed the swimming pool for an indeterminate period of time.'

In the first example sentence, the past participle gesloten 'closed' is used as an adjective within the nominal phrase het gesloten zwembad 'the closed swimming pool'. The same past participle appears in the second example as the lexical verb in the perfect construction heeft gesloten 'has closed'. Both examples illustrate that the past participle can have an adjectival as well as a verbal analysis depending on the particular phrase or construction it appears in.

The categorization of the past participle gets even more troublesome when it is combined with the stative verb zijn 'to be', as is exemplified in the next classical Example (3):
(3) Het zwembad
is gesloten.
the swimming.pool is closed
'The swimming pool is closed.'

Within this particular construction, the past participle gesloten 'closed' can receive both an adjectival and a verbal analysis. In the traditional literature, the past participle is either considered as an adjective within a copula construction or as a lexical verb within a passive construction (e.g., Michels 1959; ANS 1997). What is typical of this traditional approach is that each structural analysis correlates with a distinct semantic interpretation. On the one hand, the adjectival analysis of the past participle is argued to highlight the present state of the subject, whereas the verbal analysis, on the other hand, is said to focus on the past process expressed by the verb stem of the past participle. A similar differentiation can be found between an adjectival and a verbal analysis for the past participle in the more recent generative literature. Since the work of Wasow (1977), constructions with zijn 'to be' and a past participle have been systematically analyzed as either an adjectival or a verbal passive, with the past participle possessing typical adjectival or verbal properties. 
In order to disambiguate the past participle, numerous researchers working both within the traditional and the generative framework have been searching for diagnostics to discriminate between the adjectival and verbal analysis in particular contexts of usage (Wasow 1977; Levin and Rappaport 1986; Embick 2004; Maienborn 2007). Example (4) and (5) demonstrate some of the most classical criteria that are suggested in the literature to disambiguate Example (3):

$\begin{array}{ll}\text { Zwembad } & \text { Stadspark is sinds } 23 \text { oktober continu } \\ \text { swimming.pool } & \text { Stadspark is since } 23 \text { October continuously } \\ \text { gesloten door problemen aan het elektriciteitsnet. } \\ \text { closed by problems on the electricity.grid }\end{array}$

'Swimming pool Stadspark has been closed without interruption since 23 October because of problems with the electricity grid.'

(5) Drie scholen in New York zijn door het stadsbestuur
three schools in New York are by the city.council
gesloten omdat er een uitbraak werd vastgesteld
closed because there a breakout became established
van Mexicaanse griep.
of Mexican flu

'Three New York schools have been closed by the city council because of a breakout of the swine flu.'

In Example (4), the durational adverb continu 'without interruption, continuously' implies that the swimming pool has remained in the state of being closed for a long period of time, thus pointing to a stative adjectival analysis of the past participle. In Example (5), on the other hand, the addition of the agent of the process expressed in the past participle door het stadsbestuur 'by the city council' highlights the actual process of closing the schools in the past, thus implying a processual verbal analysis of the past participle. Another classical test to distinguish an adjectival analysis from a verbal analysis in Dutch is to determine whether it can be combined with a perfect. For the adjectival interpretation, this does not pose any problems (e.g., het zwembad is continu gesloten geweest 'the swimming pool has been closed without interruption'). For a verbal past participle, however, this is problematic, as it is impossible in modern Dutch to form a perfect on the basis of a perfect (e.g., *het zwembad is door het stadsbestuur gesloten geweest 'the swimming pool has been closed by the city council').

The persistent aim in the existing literature to disambiguate the past participle affirms that ambiguity is considered to be a problematic quality for linguistic description. Both the traditional and generative lines of research have tried to resolve this issue by formulating disambiguating criteria that indicate a preferred interpretation. More specifically, within generative grammar ambiguity 
is seen as the result of multiple deep structures that are mapped onto the same surface structure. Thus, this preoccupation with disambiguating the past participle should be understood as a continuing quest for the underlying syntactic structure of the past participle. In the words of Wasow (1977: 338), it can be said that contextual criteria allow language users to determine whether "some passive participles are adjectives while others are verbs".

The search to disambiguate the past participle in actual language use inevitably faces some empirical limitations. First of all, every criterion suggested in the literature only covers a limited amount of contexts for the past participle. Take, for example, the diagnostic of an explicit agent in passive constructions - as demonstrated in Example (5) - which suggests a verbal analysis of the past participle. Corpus research has shown that this explicit agent is only rarely present in passive sentences (Svartvik 1966 for English; Cornelis and Verhagen 1995 for Dutch). Similar observations can be made for other diagnostics, such as the presence of adverbials that point to either an adjectival or a verbal analysis. Thus, every criterion individually only applies to a rather limited range of usages. In order to overcome this limitation, scholars usually combine a series of diagnostics in order to expand the range of past participles that are covered. However, even the combination of all state-of-the art criteria together does not guarantee a full coverage of all past participles in actual use. De Sutter (2005), for instance, used a comprehensive algorithm based on diverse semantic, morphological, syntactic and frequency criteria that were taken from the literature, in an attempt to classify the past participle in the Dutch zijn 'to be' constructions. Even with this wide range of criteria, 71 out of the 841 past participles could still not be disambiguated, as no definite choice could be made between an adjectival and a verbal analysis. In sum, despite the diverse criteria suggested in the literature, many instances of the past participle still remain ambiguous in actual language use.

Of course, one could argue that some past participles remain ambiguous because of our yet incomplete understanding of the diagnostics that indicate a preference for an adjectival or a verbal analysis. However, the fact that many past participles are ambiguous in real language use — both before and after disambiguation efforts - should not be swept under the carpet. To my mind, this only demonstrates that the traditional and generative literature have nothing fundamental to say about ambiguity in real language usage. In this article, I will therefore put forward an alternative way to analyze Dutch past participles, taking these ambiguous cases in real language usage seriously. Thus, my standpoint is fundamentally usage-based, as it is essential that observations of real language use are fully integrated into the description of the past participle. More specifically, my analysis of the past participle will highlight the semantic interpretation of the past participle rather than its structural properties, which have been the focus of the attention until now. 
This article is structured in the following way. In the first two sections, I will elaborate on the ambiguous semantic interpretation of the past participle in Dutch. The provisional distinction between a stative and a processual interpretation of the past participle, as has been made in the above introduction, will be further elaborated by means of a critical survey of the literature. Here, considerable attention will be devoted to the interaction of the semantic interpretation of the past participle and its compatible contexts of usage. These two sections on the semantics of the past participle will serve as an empirical background for a third, more theoretical section dealing with the status of ambiguity in actual language use. The main line of argument in this third section will be that the ambiguity of the past participle is fundamental and that it is only to be disambiguated through context if there are conversational needs to do so.

\section{The resultative interpretation}

In the above introduction, it has been mentioned that the adjectival analysis of the past participle highlights the present state of the subject. This particular interpretation has been illustrated by means of Example (1) and (4), here repeated as (6) and (7) for convenience:

(6) Waarschijnlijk was hij met een aantal vrienden over probably was he with a number friends over een hek van het gesloten zwembad geklommen. a fence of the closed swimming.pool climbed 'He had probably been climbing over a fence of the closed swimming pool together with a couple of friends.'

(7) Zwembad Stadspark is sinds 23 oktober continu
swimming.pool Stadspark is since 23 October continuously
gesloten door problemen aan het elektriciteitsnet.
closed by problems on the electricity.grid
'Swimming pool Stadspark has been closed without interruption since
23 October because of problems with the electricity grid.'

In Example (6) and (7), the swimming pool has remained in the state of being closed for a period of time, as is highlighted explicitly by the durational adverb continu 'without interruption, continuously' in Example (7). In the literature, this particular interpretation of the past participle has been defined as designating the end state that is the result of the action or event expressed by the verb stem (Van der Wal 1986; Pardoen 1991, 1993; Duinhoven 1985, 1997; Verhagen 1992; Cornelis 1997). Traditionally, this interpretation is referred to as the stative interpretation of the past participle. However, as argued by Nedjalkov 
and Jaxontov (1988), the term 'stative' is not entirely accurate for the interpretation in question. This terminological remark can be demonstrated by comparing the so-called stative interpretation of the past participle gesloten 'closed' in Example (7) with the plain stative meaning of a prototypical adjective such as dicht 'shut' in Example (8), taken from an internet article reporting on the same swimming pool mentioned in (7):
Sinds 23 oktober is het zwembad
dicht.
since 23 October is the swimming.pool shut/closed
'The swimming pool has been closed since 23 October.'

In Example (7), the past participle gesloten 'closed' refers to the same present state of the swimming pool as the adjective dicht 'shut' in Example (8), as is indicated by the identical time adverbial sinds 23 oktober 'since 23 October'. However, in contrast to the plain adjective, the end state referred to in the past participle is conceived as the result of the process in the verb stem of the past participle in Dutch. Therefore, this specific interpretation should be more accurately termed the resultative interpretation (Nedjalkov and Jaxontov 1988; Haspelmath 1994; Nedjalkov 2001).

Only past participles of the type gespierd 'muscular', breedgeschouderd 'broad-shouldered' and welbespraakt 'eloquent' (the group of the so-called pseudo-participles) should be analyzed as pure statives rather than having a resultative interpretation, as is illustrated in Example (9) and (10):

(9) Het lichaam is lang, slank, gracieus, elegant, en toch the body is long slender gracious elegant and still mooi gespierd.

beautifully muscular

'The body is long, slender, gracious, elegant, but still nice and muscular.'

(10) Hij is bijna twee meter lang, breedgeschouderd en

he is almost two meter long broad-shouldered and

grof in de bek, vooral als hij dronken is. coarse in the beak especially if he drunk is

'He is almost two meters tall, broad-shouldered, and rude, especially when he's drunk.'

These pseudo-participles have in common that they look like regular past participles but are not formed on the basis of an existing verb stem (e.g., spier in gespierd 'muscular' is not a verb stem but a noun). Due to their isolation from the verbal paradigm, these pseudo-participles only have a stative interpretation that cannot be seen as the result of some preceding verbal process. As these participles are not considered to be prototypical past participles, their interpretation will be left aside in the remainder of the article. 
The rather complex nature of the resultative interpretation implies some limitations for the number of compatible contexts for the past participle. First, the resultative interpretation only appears to be suitable in discourse situations that involve a process leading up to a certain endpoint beyond which the process cannot continue (Nedjalkov and Jaxontov 1988; Nedjalkov 2001). Put differently, the end state that is profiled in the resultative interpretation of the past participle requires a telic discourse situation. Typically, the telicity of a discourse setting correlates with the inherent aspect or Aktionsart of the main verb of the clause. Following the verb typology of Vendler (1957), we can distinguish two verb classes that have a telic Aktionsart: (a) achievements that reach an inherent end point instantly (e.g., ontploffen 'to explode', neerschieten 'to shoot down'); and (b) accomplishments that require a longer process to arrive at the inherent end point (e.g., sluiten 'to close', bouwen 'to build', bevriezen 'to freeze'). The resultative interpretation of telic past participles is illustrated for these two verb classes - for verb stems that belong to the class of achievements in Example (11) and for the class of accomplishments in Example (12):

(11) De bom is ontploft. Zijn vernietigende $\begin{aligned} & \text { werking raast } \\ & \text { the bomb is exploded its destructive }\end{aligned}$
de hele
the wereld over.

'The bomb has exploded. Its destructive effect is raging all over the world.'

$\Rightarrow$ the bomb has reached the end state of being fully exploded
(12) De stad is gebouwd op een heuvel en heeft de the city is built on a hill and has the bossen van de Monteluco als een groen decor. woods of the Monteluco as a green scenery 'The city is built on a hill and has the woods of Monteluco as green scenery.'
$\Rightarrow$ the city has reached the end state of being fully built

Note that the resultative interpretation of Example (11) and (12) becomes salient by means of the surrounding context. In Example (11), the second clause describes the destructive result of the explosion denoted by the past participle in the first clause. In Example (12), the focus of the discourse lies on a description of the present appearance of the city.

Verb stems that have an atelic inherent aspect do not concur with the resultative interpretation of the past participle. Van der Wal (1986: 71-72) has pointed out that monovalent verbs that have no inherent end state (e.g., wandelen 'to walk', lachen 'to laugh', slapen 'to sleep') are incompatible with past 
participles that have a resultative interpretation, as is illustrated in the construed Examples (13) and (14):

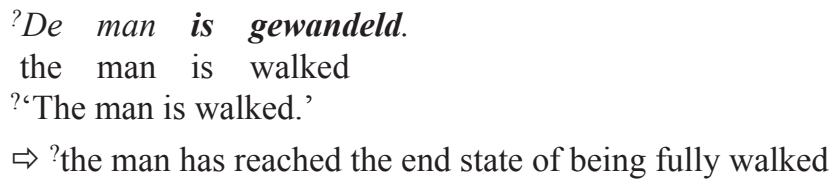

This incompatibility of atelic Aktionsart and resultative interpretation, however, is not limited to solely monovalent verb stems. As De Haan (1997: 95) remarks, also atelic divalent verb stems are not compatible with past participles that receive a resultative interpretation. This tendency can be exemplified with the construed Example (15), containing the past participle of the stative transitive verb seen 'to see':

$$
\begin{aligned}
& \text { ?De dief is gezien. } \\
& \text { the thief is seen } \\
& \text { ?'The thief is seen.' } \\
& \Rightarrow \text { ? the thief has reached the end state of being fully seen }
\end{aligned}
$$

Some of the above atelic verb stems can be used as a past participle with a resultative interpretation, if some contextual information is added that makes the discourse setting telic. In the authentic Example (16), the atelic verb wandelen 'to walk' is combined with an adverbial directional complement naar huis 'home':

$$
\begin{aligned}
& \mathrm{Na} \text { een stukje meegelift te zijn met een } \\
& \text { after a little.piece along.hitchhiked to be with a } \\
& \text { toeristisch straattrammetje zijn we rustig naar huis } \\
& \text { touristic little.street.tram are we quietly to home }
\end{aligned}
$$

The above example is an illustration of the more general tendency that the aspect of a clause is not only determined by the Aktionsart of the main verb but also by other contextual elements in that clause, as has been demonstrated in the work of Verkuyl (1972) and Dowty (1979). In sum, the resultative interpre- 
tation of past participles requires a telic discourse situation, which can be reached by either using a verb stem with a telic Aktionsart or by adding telic contextual elements to the clause.

Next to limitations on the aspectual properties of the discourse situation, the resultative interpretation of the past participle also imposes certain requirements on the participants that are involved in the discourse. In the resultative interpretation, the discourse needs to involve a participant who undergoes the action or event expressed in the verb stem and who is fully affected by the process at its end point. This can again be elucidated by means of Example (6) and (7) from the beginning of this section. In both examples, it is the swimming pool that has undergone the process of being closed in the past. Moreover, as a result of that closing process, the swimming pool has reached the end state of being fully closed at the moment of speaking. The semantic role of the undergoing participant in this example is typically referred to as the patient. However, the undergoing participant that is fully affected by the resultative interpretation is not confined to the semantic role of patient in prototypical transitive discourse situations. Therefore, I will refer to this undergoing participant with the more general semantic macrorole of undergoer that has been proposed in role and reference grammar (Van Valin and LaPolla 1997). To conclude, the resultative interpretation of the past participle is only compatible with discourse situations that have an undergoer orientation (Comrie 1981; Haspelmath 1994; Broekhuis 1997; Cornelis 1997; De Haan 1997; Duinhoven 1997).

The undergoer orientation of the resultative interpretation has several implications for the semantic valence of the verb stem in the past participle. This verb stem needs a participant in its inherent valence that can be analyzed as the undergoer of the event or action. Some typical representatives of these verbs are transitive verbs, which always have an undergoer (e.g., sluiten 'to close', opsteken 'to put up', neerschieten 'to shoot down'). However, there are also monovalent verbs that have an undergoer as their only participant (e.g., ontploffen 'to explode', bevriezen 'to freeze'). In Examples (6), (7), (11), (12) and (16), authentic attestations are given that illustrate the resultative interpretation of both monovalent and divalent past participles combined with the finite verb zijn 'to be'. It should be noted that the undergoer of a resultative past participle can also appear as the direct object of the finite verb hebben 'to have', as is shown in Example (17):

Prinses Mette-Marit draagt een wit jurkje met een
princess Mette-Marit wears a white dress with a
creme/beige jas erover
cream/beige coat there.over across she has her hairs
opgestoken en ze heeft een opvallende goude[sic]
up.put
and she has a eye-catching golden


horloge om.

watch around

'Princess Mette-Marit is wearing a white dress with a cream/beige coat over it. She wears her hair up and she has an eye-catching golden

watch on.'

$\Rightarrow$ the hair has reached the end state of being fully up

Conversely, verb stems that do not have an undergoer in their valence are not compatible with a resultative interpretation. De Haan (1997: 97) points out that monovalent atelic verbs (e.g., wandelen 'to walk', lachen 'to laugh', slapen 'to sleep') are not only incompatible with the resultative interpretation of the past participle because of their atelic inherent aspect, but also because of the lack of an inherent undergoer in their valence, as is affirmed by Examples (13) and (14). It is not a coincidence that an inherent atelic aspect and the absence of an inherent undergoer go hand in hand in atelic monovalent verbs stems. Van Valin and LaPolla (1997: 151) state that the semantic macro role of the single participant in monovalent verbs follows a general principle: if a monovalent verb has an atelic inherent aspect, it selects an undergoer participant as its single participant.

As has been demonstrated earlier in Example (16), a monovalent atelic verb such as wandelen 'to walk' can occur in past participles with a resultative interpretation. It has been shown that adding telic contextual elements to the clause increases the acceptability of a resultative interpretation for the atelic monovalent past participle. The same impact of context can be observed for the participants involved in the discourse setting. In Example (18), the monovalent verb wandelen 'to walk' is combined with the additional argument een heel eind 'a long way'. With this new participant, a potential undergoer of the action in the verb stem is introduced into the discourse that is more compatible with a resultative interpretation of the past participle than the subject we 'we' is:

We zijn dan ondanks de vermoeidheid $\frac{\text { een heel eind }}{\text { we are then despite the fatigue }}$ a whole end
we verder omhoog gewandeld tot de plek waar we die further upwards walked until the spot where we that keer met de snowscooters waren gestopt om time with the snow.scooters were stopped in.order.to foto's te maken. pictures to make

'Despite our fatigue, we then walked a long way further uphill until we reached the spot where we once got off our snow scooters to take some pictures.'

$\Rightarrow$ the distance has reached the end state of having fully walked 
The above example shows that the participants involved in the discourse are not solely determined by the valence of the verb stem, but that transitivity just as telicity - appears to be discourse determined. Since the work of Hopper and Thompson (1980) and Rice (1987), it has been common knowledge that the transitivity of a clause is not only affected by the inherent valence of the main verb but also by other discourse parameters, such as the telicity of the process in the clause and the extent to which the undergoer participant is fully affected by that process. In Example (18), the overall transitivity of the clause is increased by adding the argument een heel eind 'a long way', which is fully affected by the activity of walking. Moreover, the presence of the directional adverb verder omhoog 'further uphill' points to a similarly heightened transitivity of the clause. The fact that both a high telicity and a fully affected undergoer correlate with transitivity is predicted by the transitivity hypothesis of Hopper and Thompson (1980: 255).

In sum, the resultative interpretation of the past participle is defined as designating the end state that is the result of the action or event expressed in the verb stem. This particular interpretation only appears to be compatible with telic discourse contexts that involve a process leading up to a certain endpoint beyond which the process cannot continue. Moreover, the resultative interpretation requires a participant in the discourse that undergoes the process in the verb stem until it is fully affected by this process in its final stage.

\section{The processual interpretation}

After having elaborated the resultative interpretation of the past participle, more flesh will be put in this section on the processual interpretation that has been shortly mentioned in the introduction. This processual interpretation of the past participle has been illustrated by means of Example (2) and (5), here repeated as (19) and (20) for convenience:

(19) Jacques Gobert, de burgemeester van La Louvière, heeft Jacques Gobert the mayor of La Louvière has het zwembad voor onbepaalde tijd gesloten. the swimming.pool for indeterminate time closed 'Jacques Gobert, the mayor of La Louvière, has closed the swimming pool for an indeterminate period of time.'

Drie scholen in New York zijn $\frac{\text { door het stadsbestuur }}{\text { three schools in New York are by the city.council }}$
gesloten omdat er een uitbraak werd vastgesteld
closed because there a breakout became established




\section{van Mexicaanse griep. \\ of Mexican flu}

'Three New York schools have been closed by the city council because of a breakout of the swine flu.'

In both examples, the process of closing the swimming pool/schools in the past is in focus rather than the present result of that process, as is highlighted by the agent door het stadsbestuur 'by the city council' that performed the process of closing in Example (20). More generally, the past participle in both examples profiles all the states within the process in the verb stem as it unfolds, not just the final state. In the literature, this interpretation is referred to as the processual interpretation of the past participle (Langacker 1982; Duinhoven 1985, 1997; Van der Wal 1986; Pardoen 1991, 1993).

The processual interpretation of the past participle appears to be less restricted in compatible contexts of usage than the resultative interpretation that was only compatible with telic discourse situations involving an undergoing participant. First, since the processual interpretation of the past participle profiles all the states within the process in the verb stem, there is no compelling need of limiting the discourse situation to telic situations (Nedjalkov and Jaxontov 1988; Nedjalkov 2001). Put otherwise, the processual interpretation of the past participle is compatible with both atelic and telic discourse situations. This implies that the atelic verbs of the previous section, that were only compatible with resultative past participles by means of contextual elements, can be applied much more freely with a processual interpretation. In Example (21) and (22), it is shown how the atelic activity verbs wandelen 'to walk' and lachen 'to laugh' receive a processual interpretation without an implied end result:

De hele verdere middag hebben we lekker
the whole further afternoon have we pleasantly
gewandeld door SOHO en Little Italy.
walked through SoHo and Little Italy

'The rest of the afternoon, we had a pleasant walk through SoHo and Little Italy.'

$\Rightarrow$ we have performed the activity of walking

(22) Heel de wereld heeft smakelijk gelachen om de whole the world has heartily laughed about the gekke, dronken Gibson. crazy drunk Gibson 'The whole world has laughed heartily at crazy, drunk Gibson.' $\Rightarrow$ the whole world has performed the activity of laughing 
The processual interpretation is not limited to verbs that designate an atelic activity but is also compatible with atelic states, in the terminology of Vendler (1957). In Example (23), the subsequent states the subject goes through are profiled, again without implying that a final end state is reached:

$$
\begin{aligned}
& \text { Ik zoek getuigen die deze aanrijding hebben gezien } \\
& \text { I search witnesses that this collision have seen } \\
& \text { en willen verklaren wat zij hebben gezien. } \\
& \text { and want declare what they have seen } \\
& \text { 'I am looking for witnesses that have seen this collision and who want } \\
& \text { to declare what they have seen.' } \\
& \Rightarrow \text { the witness has 'performed the states of seeing' the collision }
\end{aligned}
$$

Note that the processual interpretation is not restricted to atelic verb stems or atelic discourse situations (as is argued by De Haan 1997: 96), but that it is also compatible with telic discourse environments. In Example (24) and (25), next to the resultative interpretation that was illustrated above in Examples (11) and (17), there is also a processual interpretation possible that profiles all the states the process goes through, not only the final state:

Het licht van een ster die dertien miljard jaar
the light of a star that thirteen billion year
geleden ontplof is, heeft de aarde bereikt.
ago exploded is has the earth reached

'The light of a star that exploded thirteen billion years ago has reached the earth.'

$\Rightarrow$ the star performed the process of exploding

$$
\begin{aligned}
& \text { Ik ben bij mijn gewoonlijke kapper geweest en } \\
& \text { I am with my ordinary hair.dresser been and } \\
& \text { die heeft mijn haar opgestoken. } \\
& \text { that.one has my hair up.put } \\
& \text { 'I have been to my ordinary hair dresser and he/she has put up my } \\
& \text { hair.' } \\
& \Rightarrow \text { the hair dresser has performed the process of putting up the hair }
\end{aligned}
$$

The processual interpretation of the past participle also does not impose any restriction on discourse situations that involve an undergoing participant. Since the end state is not profiled that the undergoer has reached as the result of the process in the verb stem, this undergoer does not necessarily has to be present in the discourse. In Example (21), the monovalent atelic verb stem wandelen 'to walk' only selects an agent participant in its valence scheme. The absence of an undergoer in the clause, however, does not prevent a processual interpretation of the past participle. In Example (26), the divalent verb stem bouwen 
'to build' does allow for an undergoer in its valence. However, in this particular example, the undergoer participant is not expressed since the focus of the discourse is on the continuous process of building in the past, rather than on the specific edifices that have been erected as the result of these past construction efforts:

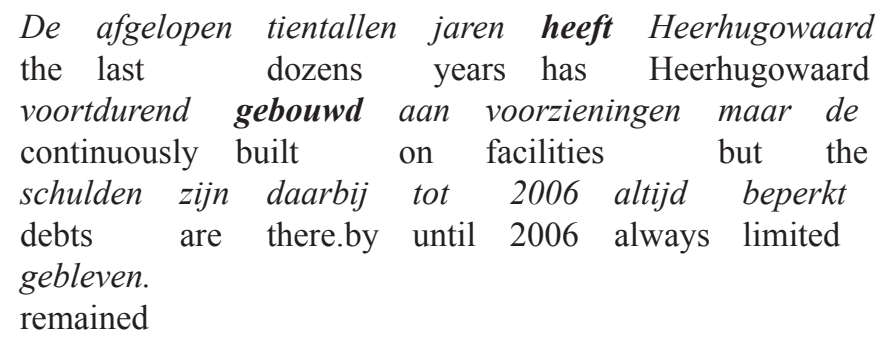

'In the last decades, Heerhugowaard was continuously building on facilities but the debts always remained limited until 2006.'

$\Rightarrow$ Heerhugowaard has performed the process of building

In contrast to the resultative interpretation of the past participle, the processual interpretation is not undergoer-oriented but rather increases the salience of the agent or - put more generally in role and reference terms - the actor of the process in the verb stem (Duinhoven 1997: 276). In the examples on processual past participles discussed until now, i.e., Examples (19)-(26), the subject of the clause acts as the focal participant of the process in the verb stem, as can be noticed from the short paraphrases below each examples sentence. This interpretation of the subject of the clause as the actor of the process in the past participle is typical for the perfect construction that in Dutch typically consists of the auxiliary verb hebben 'to have' and a past participle. However, the auxiliary verb zijn 'to be' in combination with past participles of monovalent telic verb stems also plays a minor role of importance as a perfect construction, if the subject of the clause can be both interpreted as the undergoer of the process in the verb stem as well as the actor of that process, as in Example (24).

The processual interpretation is however not limited to cases where the actor is present in the discourse. Consider Example (20), where the divalent past participles gesloten 'closed' is combined with the auxiliary verb zijn 'to be' in one construction. As the valence of zijn 'to be' only allows for one participant, only the undergoer participant of the past participle is expressed. The actor of the two divalent main verbs, however, is not completely absent from this particular discourse setting. It is not uncommon in Dutch to express the actor of the past participle by means of a prepositional phrase introduced by door 'by'. This specific type of processual interpretation of constructions with zijn 'to be' and a past participle is typical for the passive construction. 
In sum, next to a resultative interpretation, the past participle can be attributed a processual interpretation that highlights all the states within the process in the verb stem as it unfolds, not just the final state. This interpretation is not only compatible with telic discourse situations that are undergoer-oriented but also with atelic discourse situations with an actor participant.

\section{The relation between resultative and processual interpretation}

In the preceding sections, the diverse interpretations of the past participle have been discussed separately from each other. This semantic description of the past participle will now serve as an empirical background for a more detailed analysis of the exact relation of both interpretations of the past participle. Here, the main focus will be on the status of ambiguous past participles that both allow for a resultative and a processual interpretation in actual discourse.

In the previous sections, it has been shown that the resultative interpretation of the past participle, on the one hand, is only compatible with telic discourse contexts that are undergoer-oriented. The processual interpretation, on the other hand, is applicable in both telic and atelic discourse settings that are rather actor-oriented. If we now compare the range of contexts for both interpretations, it appears that the processual interpretation is broader and more general in nature than the rather restricted resultative interpretation. Furthermore, the limited discourse context of the resultative interpretation seems to be a subset of the more general processual interpretation: the telic discourse settings to which the resultative interpretation is confined are also compatible with a processual interpretation. This relation, with the processual interpretation enclosing as it were the resultative interpretation, is visualized in Figure 1.

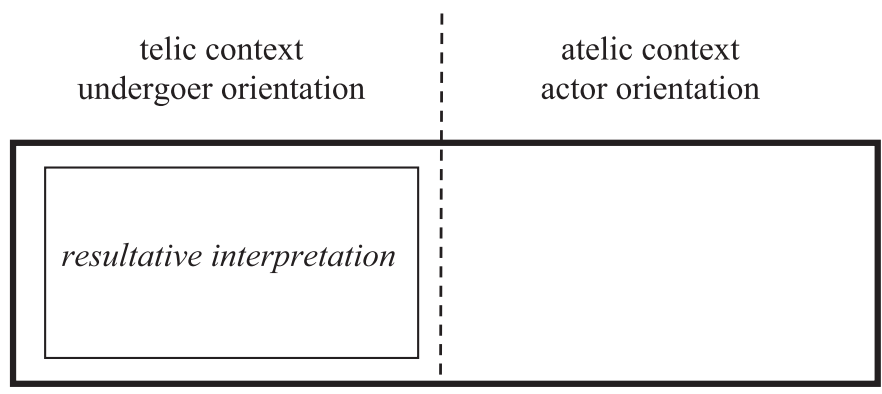

processual interpretation

Figure 1. Contextual compatibility of the resultative and processual interpretation of the past participle 
Figure 1 shows how the telic discourse contexts that are undergoer-oriented are only a subset of all the compatible contexts of usage of the processual interpretation. Thus, the processual interpretation is more general in usage and meaning than the resultative interpretation, which is restricted to a subset of telic discourse contexts. It is striking that this relation, in which the processual interpretation encompasses the resultative interpretation, is generally overlooked in the literature. This is especially striking within the generative tradition, which considers both analyses as diametrically opposed to each other. Still, it is important to acknowledge this inclusive relation, since it implies that the only past participles that are truly ambiguous are the ones that appear in telic undergoer-oriented discourse contexts. Hence, other past participles that are used in atelic discourse contexts or in contexts without an undergoer participant are not ambiguous and invariably receive a processual interpretation.

Now that the range of truly ambiguous past participles is properly delimited to telic discourse situations that are undergoer-oriented, the question can be addressed how we should conceptualize the relation between the resultative and the processual interpretation in this particular discourse context. In the introduction, some contextual disambiguating criteria from the traditional and generative literature have been discussed. For convenience sake, the role of these contextual criteria will be briefly recapitulated with the classic examples sentences, repeated here as (27), (28), and (29):

\section{Het zwembad is gesloten.}

the swimming.pool is closed

'The swimming pool is closed.'

Zwembad Stadspark is sinds 23 oktober continu
swimming.pool Stadspark is since 23 October continuously
gesloten door problemen aan het elektriciteitsnet.
closed by problems on the electricity.grid
'Swimming pool Stadspark has been closed without interruption since 23 October because of problems with the electricity grid.'

Drie scholen in New York zijn door het stadsbestuur
three schools in New York are by the city.council
gesloten omdat er $\quad$ een uitbraak werd vastgesteld
closed because there a breakout became established
van Mexicaanse griep.
of Mexican flu

'Three New York schools have been closed by the city council because of a breakout of the swine flu.' 
In Example (28), the durational adverb continu 'interruptedly, continuously' highlights the maintained closed state of the swimming pool at the moment of speaking, thus pointing to a resultative interpretation of the past participle. In Example (29), the agent of the process in the verb stem door het stadbestuur 'by the city council' stresses the actual process of closing the schools in the past, which indicates a processual interpretation. As has been argued in the introduction, these disambiguation criteria are employed in the literature to uncover the underlying analysis of the past participle, which is considered to be either adjectival or verbal. This rather black-and-white view, however, downright discards past participles that cannot be disambiguated by means of contextual criteria in the clause, such as Example (27).

As an alternative, I therefore propose a fresh analysis of the past participle, finally taking the ambiguous past participles in actual discourse seriously. In line with Langacker (1982: 61), I consider the interpretation of the past participle to be fundamentally ambiguous in telic undergoer-oriented discourse contexts, unless a preference is indicated by additional material. This rather accommodating attitude towards ambiguity should be understood in light of Grice's conversational maxims of quantity (1975):

- Make your contribution as informative as is required for the current purpose of the exchange

- Do not make your contribution more informative than is required

In accordance with both pragmatic principles, I assume that the past participle remains ambiguous if there is no conversational need to specify the interpretation of the past participle in the clause. In this perspective, the absence of any contextual criterion that points to either a resultative or a processual interpretation of the past participle in actual discourse - as is the case in Example (27) - should be considered as the natural baseline in conservation rather than a problematic situation that prevents an adequate categorization of the past participle. Conversely, the precise interpretation of the past participle is only specified through additional contextual information when this information is relevant for the goal of the conversation. In Example (28), the resultative interpretation has an increased salience by adding a durational adverb, and in Example (29) the processual component of the past participle has gained in prominence by additional contextual information.

This pragmatic viewpoint on the ambiguity of the past participle can be elaborated by discussing the ambiguous Example (27) in its wider discourse context. This particular example was found in an announcement on the homepage of the Belgian coast city of Bredene in order to inform inhabitants and tourists that the swimming pool had been closed. The whole announcement is provided in Example (30): 


\section{(30) Het zwembad is gesloten!}

De jaarlijkse onderhoudsbeurt zorgt ervoor dat het gemeentelijk zwembad momenteel gesloten is voor het publiek. Nog 21 december en nadien van 25 tot en met 28 december kan er niet gezwommen worden.

'Due to its annual maintenance, the municipal swimming pool is closed for the general public. On 21 December and afterwards from 25 until 28 December it is therefore not possible to go swimming.'

As argued above, the initial clause of the announcement, i.e., het zwembad is gesloten, does not specify whether it is the present closed state of the swimming pool that is highlighted or the past process of closing that has led to that present state. The surrounding discourse context suggests that it is mainly the resulting state that is salient in this announcement, as potential visitors are warned that swimming is impossible at present and will be in the near future. However, the announcement also specifies why the swimming pool is closed, thus stressing the past process of closing the swimming pool to some extent. Nevertheless, neither the resultative nor the processual interpretation of the past participle gesloten 'closed' are disambiguated in the initial clause, because at that time it is sufficient for the goals of the utterance to merely state that the swimming pool is closed. The same argumentation can be elaborated for the past participles in Examples (11), (12), (17), (24), and (25), which are used in a telic undergoer-oriented discourse context without any explicit disambiguating criterion.

One way to conceive the varying salience of the resultative and processual interpretation in actual discourse is by using the imagery of a pair of scales. As long as no particular contextual clue (or an equal amount of them) puts forward either a resultative or a processual interpretation in actual discourse, both meaning components of the past participle are in balance. In that case, the interpretation is ambiguous, as in Example (27). As soon as there is a disambiguating criterion in the discourse, the metaphorical scale tilts towards the corresponding interpretation of the past participle. In that case, we are dealing with a salient resultative interpretation, as in Example (28), or with a salient processual interpretation, as in Example (29). This imagery of the pair of scales has a formalized correlate that was suggested by Langacker (1991: 270) in order to represent the relative salience of meaning components within one construction. In this system, salient parts of the construction meaning are placed inside heavy-line boxes and less prominent components of that same construction are put in lighter dashed-line boxes. In Figures 2 to 4, the relative salience of the resultative and the processual interpretation of the past participle is represented according to this system for example sentences (27), (28) en (29): 


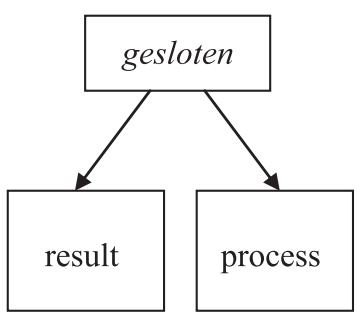

Figure 2. Ambiguous interpretation of Example (28)

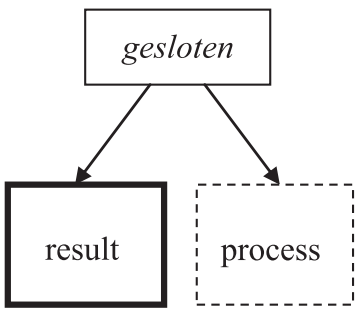

Figure 3. Salient resultative interpretation of Example (27)

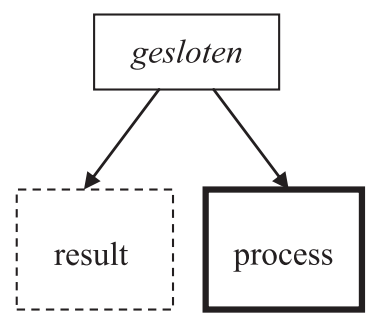

Figure 4. Salient processual interpretation of Example (29)

Although the Figures 2 to 4 are very straightforward to interpret, they do display the fundamental ambiguity of the past participle in a strictly binary way. The representation of the resultative and processual interpretation in two distinct boxes inevitably suggests some categorical choice in interpretation that is reminiscent of the traditional and generative analysis of the past participle. However, I do not see disambiguation by means of contextual information as a categorical but rather as a gradual process, in which the salience of one interpretation is higher than the other interpretation. This point of view is supported by corpus research from De Sutter (2005), who has developed a disambiguation algorithm for past participles in constructions with zijn 'to be' 
in Dutch. What is inspiring in his approach is the classification of past participles on a continuous scale ranging from extremely adjectival to extremely verbal. This gradual classification demonstrates that the interpretation of past participles does not solely cluster at the extreme adjectival or verbal end of the continuum, but that various intermediate values are also possible. In order to underline the gradual nature of contextual disambiguation, I therefore suggest the following alternative metaphor of the continuum in order to represent the varying interpretation of the past participle (as is also suggested by De Haan 1997: 91):

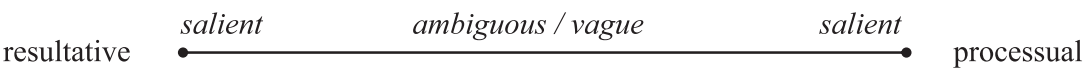

Figure 5. Continuum representation of ambiguous past participles

In contrast to the above Figures 2 to 4 with boxes, the representation of the ambiguous past participle on a continuum allows for other interpretations next to a salient resultative or processual one. It facilitates considering intermediate interpretations of the past participle that might have a relatively high salient resultative or processual interpretation but still contain some degree of ambiguity. In Example (24), for instance, the time adverbial dertien miljard jaar geleden obviously highlights the past time reference of the process of exploding. However, as the past participle ontploft 'exploded' is used in a relative clause that expands on the present state of the exploded star, the resulting state of the process of exploding is also salient to some extent. These intermediate values are referred to as ambiguous or vague in the continuum representation in Figure 5. The introduction of the term 'vague' is inspired by Langacker (1999: 125), who has pointed out that it is a classical problem in lexical semantics to determine whether the interpretation of an expression is truly ambiguous (in the sense that we have to posit two senses) or whether it is merely vague (meaning that it only has one sense). We need to ask ourselves the question how the interpretation of the past participle is conceptualized in contexts where there are no conclusive contextual clues to one interpretation or the other. Are the resultative and the processual meaning simultaneously accessible to the interlocutors, so that we can safely state that the interpretation is ambiguous, or is there rather a more unified vague interpretation of the past participle? Langacker indicates that it is hard to draw the line in practice, as judgments of ambiguity are often graded.

It would be interesting for future investigation to further unravel the status of intermediate interpretations of the past participle by means of empirical data. It would, for example, be valuable to reanalyze the data of De Sutter (2005) in terms of the type of contextual clues that allow language users to 
disambiguate the past participle and the incidence of these clues in actual discourse. Would the intermediate interpretations reported in De Sutter (2005) predominantly correlate with the absence of any contextual clue (thus giving support to the vagueness hypothesis), or would they be more in line with conflicting contextual clues that point to both a resultative and processual interpretation simultaneously (thus underpinning the ambiguity scenario)? Until these more fine-grained data become available, I choose to remain agnostic about the exact status of the intermediate interpretation of the past participle as being either ambiguous or vague.

In order to conclude the discussion on the ambiguous past participles, the continuum analysis should be integrated into the general interpretation scheme of the past participle that has been presented above. The following Figure 6 therefore represents an extended version of Figure 1:

\begin{tabular}{|c|c|c|}
\hline \multirow[b]{2}{*}{ resultative context } & $\begin{array}{c}\text { telic context } \\
\text { undergoer orientation }\end{array}$ & $\begin{array}{l}\text { atelic context } \\
\text { actor orientation }\end{array}$ \\
\hline & salient resultative & \multirow{3}{*}{ processual interpretation } \\
\hline & ambiguous / vague & \\
\hline processual context & salient processual & \\
\hline
\end{tabular}

Figure 6. Contextual compatibility of the resultative and processual interpretation of the past participle, extended version

In the extended Figure 6, the ambiguous part participle in telic undergoeroriented contexts is represented as a perpendicular continuum ranging from a salient resultative interpretation over an ambiguous/vague interpretation to a salient processual interpretation, depending on the particular additional contextual information. The processual interpretation in atelic contexts remains unaltered since it is not fundamentally ambiguous in nature.

\section{Conclusion}

In this article, the longstanding debate on the ambiguous interpretation of the past participle has been approached from a fresh usage-based perspective. An alternative analysis has been proposed for the current traditional and generative analysis of the past participle as being either an adjective or a verb depending on the context. In order to also include past participles in the description that cannot be disambiguated in context, this alternative analysis considers past participles to be fundamentally ambiguous unless additional contextual elements 
indicate a preference. This viewpoint on ambiguity is supported by the conversational maxims of quantity, according to which a contribution should only be as informative as is necessary for the goal of the conversation. In this perspective, contextual elements that point to either a resultative or a processual interpretation are only added if the conversation requires the disambiguation of the past participle. Moreover, in the alternative analysis of the past participle the role of contextual indicators is seen as gradual in nature rather than categorical. Thus, adding contextual elements that imply a resultative or processual interpretation increases the salience of the one interpretation rather than excluding the other interpretation.

Received 10 September 2009

Ghent University

Revised version received 19 May 2010

\section{Appendix}

Example (1), (6) http://www.hln.be/hln/nl/959/Bizar/article/detail/678182/2009/02/09/ Schelmenstreek-aan-zwembad-doet-man-in-rolstoel-belanden.dhtml

Example (2), (19) http://www.vandaag.be/binnenland/16064_jongen-van-5-verdrinktin-zwembad.html

Example (3), (27), (30) http://www.bredene.be/artikel.asp?pid=1\&id=1758

Example (4), (7), (28) http://www.gva.be/antwerpen/turnhout/zwembad-nog-maareens-langer-dicht.aspx

Example (5), (20), (29) http://www.gva.be/nieuws/buitenland/aid831829/scholen-innew-york-dicht-door-uitbraak-mexicaanse-griep.aspx

Example (8) http://www.nieuwsblad.be/article/detail.aspx?articleid=GA2MREME

Example (9) http://www.everyoneweb.com/siamesekat/Pr_Update_Knooppunt Inhoud.aspx?WebID=siamesekat\&BoomID=B1\&KnooppuntID=K474\&LG=

Example (10) http://www.reisverhalengerardjacobs.nl/boeken/goudkoorts.html

Example (11) http://www.refdag.nl/artikel/1424673/Herinnering+aan+oorlog+die+niet +uitbrak.html

Example (12) http://www.meravigliosaumbria.com/fietsen_niv__.htm

Example (16) http://pindakase.blogspot.com/

Example (17) http://starlounge.celebs.nl.msn.com/index.cfm?objectid=77946

Example (18) http://troonopvolgers.web-log.nl/troonopvolgers/feest_in_thailand_60_ jaar_koning/index.html

Example (21) http://www.take-a-trip.eu/nl/reisverhaal/4 
Example (22) http://spotlight.excite.nl/nieuws/2331/Mel-Gibson-sterker-gewordendoor-publieke-vernedering

Example (23) http://www.getuigengezocht.nl/DaviWB/Pagina20.html

Example (24) http://www.standaard.be/artikel/detail.aspx?artikelid = V52H639T

Example (25) http://www.wijtrouwen.com/nl/forum/?msgid=1844\&subject=Opgestokenkapsel

Example (26) http://www.heerhugowaardsnieuwsblad.nl/nieuws/1633010-kwint-wilhet-dijkstra-niet-meer-uitleggen

\section{Notes}

1. I would like to thank Louise Cornelis, Liliane Haegeman, Joop van der Horst and Albert Oosterhof for their valuable comments on (parts of) a previous version of this article. Correspondence address: Department of Linguistics, Ghent University, Blandijnberg 2, 9000 Ghent, Belgium. E-mail: evie.cousse@ugent.be.

2. The examples provided in this article were all sentences found on the internet through a Google search that was conducted on 21 April 2010. The corresponding URLs are given in the appendix.

\section{References}

ANS. 1997. = Haeseryn, Walter, K. Romijn, Guido Geerts, Jaap de Rooij \& M. C. van den Toorn 1997. Algemene Nederlandse spraakkunst [General Dutch grammar]. Groningen: Nijhoff.

Broekhuis, Hans. 1997. Attributief en predikatief gebruikte deelwoorden [Attributively and predicatively used participles]. In Els Elffers-van Ketel, Joop van der Horst \& Wim Klooster (eds.), Grammaticaal spektakel, 23-35. Amsterdam: Vakgroep Nederlandse taalkunde.

Comrie, Bernard. 1981. Aspect. Cambridge: Cambridge University Press.

Cornelis, Louise. 1997. Passive and perspective. Amsterdam: Rodopi.

Cornelis, Louise \& Arie Verhagen. 1995. Does Dutch really have a passive? In Marcel den Dikken \& Kees Hengeveld (eds.), Linguistics in the Netherlands, 49-60. Amsterdam \& Philadelphia: John Benjamins.

De Haan, Sies. 1997. Grammaticale status en betekenis van het voltooid deelwoord in het Nederlands: Een probleemverkenning [Grammatical status and meaning of the past participle in Dutch: An exploration]. In Els Elffers-van Ketel, Joop van der Horst \& Wim Klooster (eds.), Grammaticaal spektakel, 89-101. Amsterdam: Vakgroep Nederlandse taalkunde.

De Sutter, Gert. 2005. Rood, groen, corpus! Een taalgebruiksgebaseerde analyse van woordvolgordevariatie in tweeledige werkwoordelijke eindgroepen [Red, green, corpus! A usage-based analysis of word order variation in double verbal end clusters]. Leuven: Katholieke Universiteit Leuven dissertation.

Dowty, David. 1979. Word meaning and Montague grammar: The semantics of verbs and times in generative semantics and in Montague's PTQ. Dordrecht: Reidel.

Duinhoven, A. M. 1985. De deelwoorden vroeger en nu [The participles earlier and now]. Voortgang 6. 97-138. 
Duinhoven, A. M. 1997. Middelnederlandse syntaxis: Synchroon en diachroon: Deel 2. De werkwoordgroep [Middle Dutch syntax: Synchronic and diachronic: Part 2. The verb cluster]. Groningen: Nijhoff.

Embick, David. 2004. On the structure of resultative participles in English. Linguistic Inquiry 35. 355-392.

Grice, Paul. 1975. Logic and conversation. In Donald Davidson \& Gilbert Harman (eds.), The logic of grammar, 64-75. Encino: Dickenson.

Haspelmath, Martin. 1994. Passive participles across languages. In Barbara Fox \& Paul Hopper (eds.), Voice: Form and function. Amsterdam \& Philadelphia: John Benjamins.

Hopper, Paul \& Sandra Thompson. 1980. Transitivity in grammar and discourse. Language 56. 251-299.

Langacker, Ronald. 1982. Space grammar, analysability, and the English passive. Language 58. 22-80.

Langacker, Ronald. 1991. Concept, image, and symbol: The cognitive basis of grammar. Berlin \& New York: Mouton de Gruyter.

Langacker, Ronald. 1999. Grammar and conceptualization. Berlin \& New York: Mouton de Gruyter.

Levin, Beth \& Malka Rappaport. 1986. The formation of adjectival passives. Linguistic Inquiry 17. 623-661.

Maienborn, Claudia. 2007. Das Zustandspassiv: Grammatische Einordnung — Bildungsbeschränkung - Interpretationsspielraum. Zeitschrift für Germanistische Linguistik 35. 83-114.

Michels, L. C. 1959. Op de grens van copula en hulpwerkwoorden [On the border of copulas and auxiliaries]. Taal en Tongval 11. 206-212.

Nedjalkov, Vladimir \& Sergey Jaxontov. 1988. The typology of resultative constructions. In Vladimir Nedjalkov (ed.), Typology of resultative constructions, 3-62. Amsterdam \& Philadelphia: John Benjamins.

Nedjalkov, Vladimir. 2001. Resultative constructions. In Martin Haspelmath, Ekkehard König, Wulf Oesterreicher \& Wolfgang Raible (eds.), Language typology and language universals: An international handbook, 928-941. Berlin \& New York: Mouton de Gruyter.

Pardoen, Justine. 1991. De interpretatie van zinnen met de rode en de groene volgorde [The interpretation of clauses with the red and green word order]. Forum der Letteren 32. 1-20.

Pardoen, Justine. 1993. The word order of final elements in Dutch: free variation or meaningful organisation? In Robert Kirsner (ed.), The Low Countries and beyond, 71-83. Lanham: University Press of America.

Rice, Sally. 1987. Towards a cognitive model of transitivity. San Diego: University of California San Diego dissertation.

Svartvik, Jan. 1966. On voice in the English verb. The Hague: Mouton.

Van der Wal, Marijke. 1986. Passiefproblemen in oudere taalfasen. Middelnederlands sijn I werden + participium praeteriti en de pendanten in het gotisch, engels en het duits [Passive problems in older language phases. Middle Dutch to be / to become + past participle and the correlates in Gothic, English, and German]. Leiden: Rijksuniversiteit Leiden dissertation.

Van Valin, Robert \& Randy LaPolla. 1997. Syntax. Structure, meaning and function. Cambridge: Cambridge University Press.

Vendler, Zeno. 1957. Verbs and times. The Philosophical Review 66. 143-160.

Verhagen, Arie. 1992. Praxis of linguistics: Passives in Dutch. Cognitive Linguistics 3. 301-342.

Verkuyl, Henk. 1972. On the compositional nature of the aspects. Dordrecht: Reidel.

Wasow, Thomas. 1977. Transformations and the lexicon. In Peter Culicover, Thomas Wasow \& Adrian Akmajian (eds.), Formal syntax, 327-360. New York: Academic Press. 